\title{
Department of Plant Physiology and Biochemistry of Saint Petersburg State University celebrates $150^{\text {th }}$ anniversary
}

\section{Sergei Medvedev and Gregory Pozhvanov}

Department of Plant Physiology and Biochemistry, Faculty of Biology, Saint Petersburg State University, Universitetskaya nab., 7-9, Saint Petersburg 199034, Russian Federation

Address correspondence and requests for materials to Sergei Medvedev, s.medvedev@spbu.ru

\begin{abstract}
The Department of Plant Physiology and Biochemistry of St. Petersburg State University is one of the oldest in the Faculty of Biology, and has just recently celebrated its $150^{\text {th }}$ anniversary. Here we present a short overview of its history, from its establishment in 1867 to the current date. The history of the department is comprised of individual paths of scientists who worked here over the course of fifteen decades. We highlight the major breakthroughs and scientific discoveries made by the remarkable scholars who chaired the department and co-authored research, starting with Famintsyn, Neljubow, Palladin and Kostychev in the end of the $19^{\text {th }}$ - beginning of the $20^{\text {th }}$ century, then through the Soviet times to the present; we also give an overview of the department's current scientific and educational activities.
\end{abstract}

Keywords: Plant Physiology and Biochemistry, history of science, St. Petersburg State University, Famintsyn A.S., Baranetsky O.V., Ivanovsky D. I., Neljubow D. N., Tsvet V. S., Vinogradsky S. N., Borodin I. P., Palladin V. I., Kostychev S. P., Lvov S. D., Soldatenkov S. V., Chesnokov V. A., Polevoy V. V.

\section{Introduction}

Citation: Medvedev, S. and Pozhvanov, G. 2018. Department of Plant Physiology and Biochemistry of Saint Petersburg State University celebrates $150^{\text {th }}$ anniversary. Bio. Comm. 63(1): 5-8. https://doi. org/10.21638/spbu03.2018.102

Author's information: Sergei Medvedev, Ph.D., Dr. Sci., Professor, Head of Department, orcid.ord/0000-0003-11271343; Gregory Pozhvanov, Ph.D., Assistant Professor, orcid.org/0000-0002-5622-1318

Manuscript Editor: Farida Minibayeva, Kazan Institute of Biochemistry and Biophysics, Kazan, Russia;

Guest Editor: Maria Shishova, Saint Petersburg State University, Saint Petersburg, Russia;

Received: December 20, 2017;

Accepted: April 24, 2018; not externally peer reviewed;

Copyright: (c) 2017 Medvedev and Pozhvanov. This is an open-access article distributed under the terms of the License Agreement with Saint Petersburg State University, which permits to the authors an unrestricted distribution and self-archiving free of charge.

Funding: The authors received no specific funding for this work.

Competing interests: The authors have declared that no competing interests exist.
On June 18, 1863, Alexander II, Emperor of Russia, issued the decree "On Amendment of Charters of Five Universities - St. Petersburg, Moscow, Kharkov, Kazan, and St. Vladimir's in Kiev." In that decree, he issued an instruction to the Senate: "Twelve departments are to be established within the faculties of Physics and Mathematics," including the department of "Plant Anatomy and Physiology." In the University of St. Petersburg, the decree was implemented only in 1867, when Andrei S. Famintsyn was elected as an extraordinary professor and appointed as the head of his newly established Department of Anatomy and Physiology of Plants (Fig. 1). The most fundamental studies by academician Famintsyn became the development of the symbiogenesis theory of cell organelles origin (with K.S. Mereschkowski) and the discovery (with O. V. Baranetsky) of lichens' dual nature (the symbiosis of algae and fungi). Famintsyn, for the first time ever, started teaching plant physiology as an individual academic discipline (1860-1861), introduced a practical course on plant physiology and anatomy and authored the first Russian Plant Physiology Textbook (1887). In his own apartment (Tuchkov Lane 1, Apt. 14), Famintsyn founded a plant physiology lab, the first one in Russia. In 1890, following the aforementioned decree, a study with a plant anatomy and physiology laboratory emerged within the Emperor Academy of Sciences, based on Famintsyn's lab.

The Department of Anatomy and Physiology of Plants hosted research by a number of world-renowned scientists who developed the foundations of plant physiology (I. P. Borodin, V.I. Palladin, S. P. Kostychev), soil microbiology 


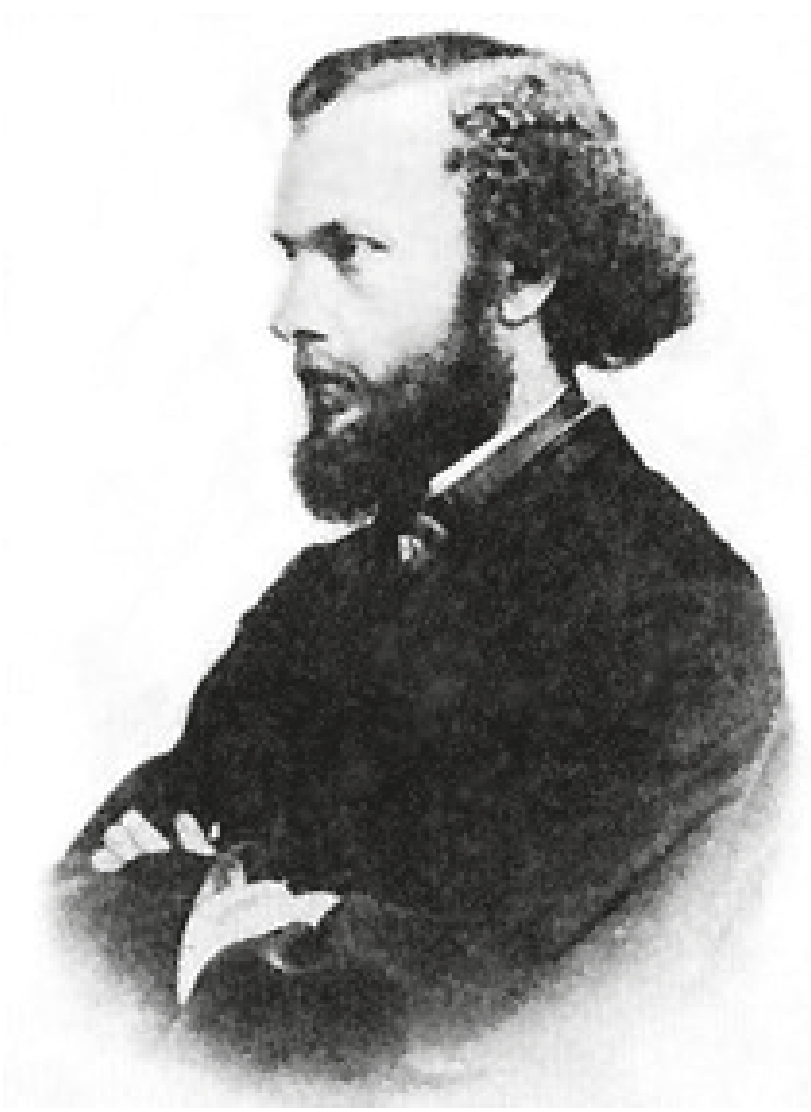

Fig. 1. Academician Andrei S. Famintsyn (1835-1918).

(S.N. Vinogradsky), virology (D.I. Ivanovsky), phytohormone ethylene (D.N.Neljubow) and chromatography (M.S. Tsvet).

In 1889, Famintsyn was elected as academician, left the chair and handed it over to Professor and, later, academician Ivan P. Borodin (1847-1930), who founded the Russian school of physiology and biochemistry of respiration. Borodin was the first to isolate chlorophyll in a crystallised state ("Borodin's crystals"). He also authored the first Russian plant anatomy textbook, Plant Anatomy Course (1888) and was one of the founders of the nature conservation system in Russia.

Dmitri I. Ivanovsky (1864-1920) was the head of the department from 1896 to 1901 . He is widely known for his discovery of the tobacco mosaic virus, which was able to pass through bacterial filters. Therefore, namely he is considered the founder of virology. In 1901, Ivanovsky lost the right to chair the department, since he had not managed to obtain a doctoral degree within a five-year term, and he was then appointed as an extraordinary professor at the University of Warsaw.

Professor Vladimir I. Palladin (1895-1922) was the head of the department beginning in 1906. He developed a totally new theory of respiration in 1907-1912, according to which respiration was described as the oxidation-reduction process consisting of two steps: an- aerobic and aerobic. According to Palladin, the universal way to oxidase the molecule (substrate) at the anaerobic step was to detach the hydrogen using special enzymes (R): $\mathrm{C}_{6} \mathrm{H}_{12} \mathrm{O}_{6}+6 \mathrm{H}_{2} \mathrm{O}+12 \mathrm{R} \rightarrow 6 \mathrm{CO}_{2}+12 \mathrm{RH}_{2}$. Then, on the second aerobic step the hydrogen was passed either to oxygen, resulting in the formation of water, or to other molecules, thus reducing them: $12 \mathrm{RH}_{2}+6 \mathrm{O}_{2} \rightarrow$ $12 \mathrm{R}+12 \mathrm{H}_{2} \mathrm{O}$. All the postulates of Palladin's theory were later confirmed using plant and animal models and were incorporated in the modern conception of respiration. After being elected as academician in 1914, Palladin handed the chair to his scholar Sergei P. Kostychev (1877-1931).

Academician Sergei P. Kostychev was the first to prove that respiration and various fermentation types share a common biochemical pathway up to some intermediate product, which, as it was later clarified, is pyruvic acid. Kostychev was one of the founders of the Plant Biochemistry and Physiology Lab ("LAFIBR" in Russian) in the Academy of Sciences in 1922, the lab which later became the basement for the Institute of Plant Physiology RAS (IPP RAS, Moscow) in 1934. Kostychev also headed the agricultural microbiology department, which was transformed in 1922 into the Institute of Agricultural Microbiology RAS. Kostychev unexpectedly died in 1931, and Sergei D. Lvov (1879-1959) became the new head of the department.

Corresponding member of the Academy of Sciences of the USSR, Sergey D. Lvov also led scientific work in the plant physiology department of the Main Botanical Garden of the Academy of Sciences (currently-Komarov Botanical Institute RAS) and was also the chair of the Department of Botany at Higher Women's Scientific Courses (formerly Bestuzhev's). The main area of his scientific research was the study of secondary metabolism in plants. In 1957, Lvov handed the chair over to Prof. Stepan V.Soldatenkov (1896-1985).

One of the results of Soldatenkov's work was the experimental confirmation of his teacher's hypothesis on the genetic connection of respiration and fermentation. He isolated a specimen of pyruvic acid and chemically identified it as the intermediate product of ethyl-alcohol fermentation and lactic acid fermentation.

At the same time, Kostychev's other remarkable scholar worked in the department - Prof. Vladimir A. Chesnokov (1905-1976). Chesnokov was the head of the plant physiology and biochemistry laboratory. His productive research on photosynthesis, hydroponics, mineral nutrition and mass algae cultivation found large-scale application in agriculture.

Professor Vsevolod V. Polevoy (1931-2001) was the head of the department in 1972-1999. The scope of his research during this period was the study of plant regulatory systems at every level of their organisation. Polevoy pioneered the research of mechanisms of phytohormone 


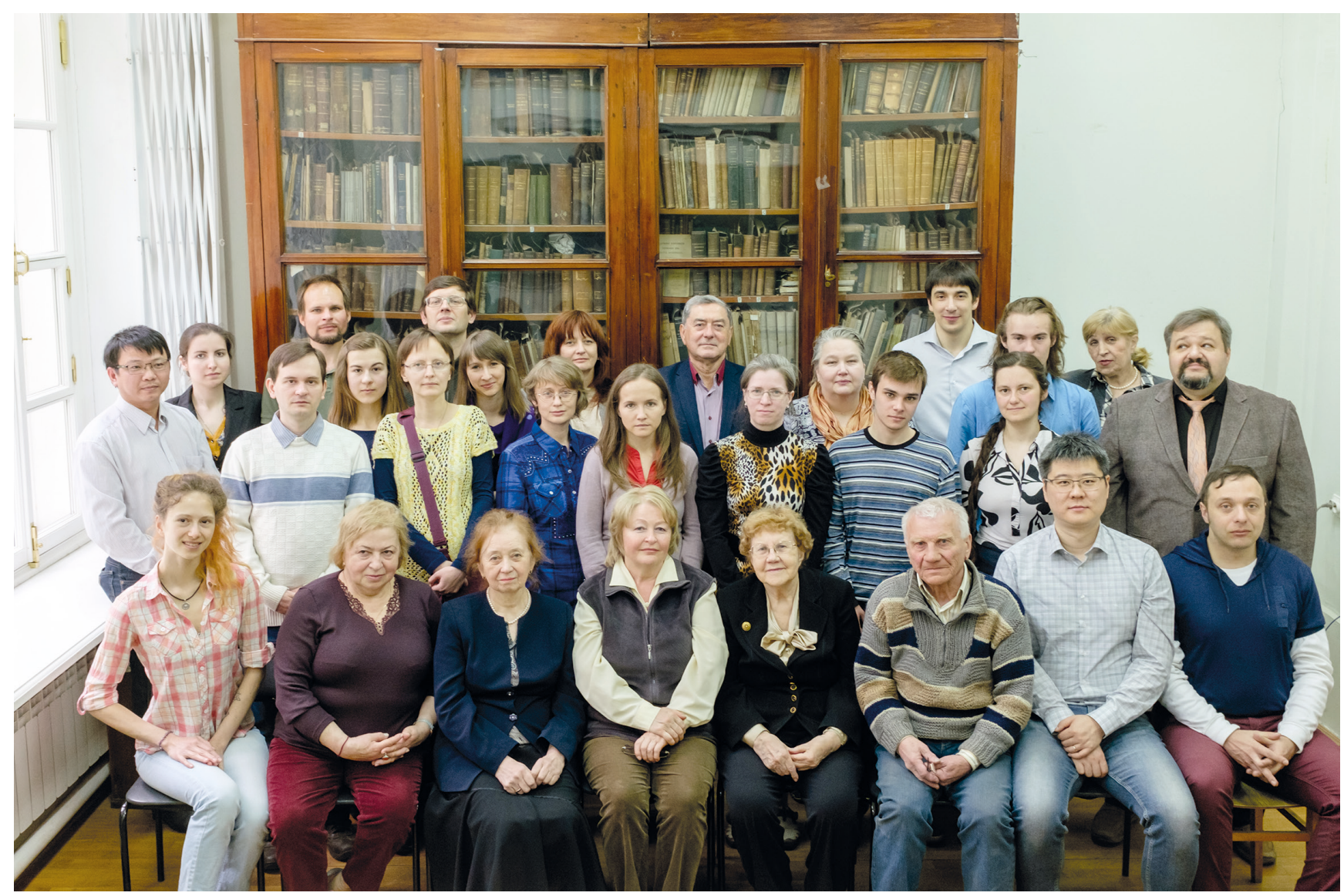

Fig. 2. Department of Plant Physiology and Biochemistry of St. Petersburg State University (photo taken on June $2^{\text {nd }}, 2017$ ).

Front row (sitting): Anastasia Bertova, Ludmila S. Sobol, Natalia G. Osmolovskaya, Ludmila N. Kuchaeva, Tamara V. Chirkova, Yuri I. Shevtsov, Tingzhuo Chen, Roman K. Puzanskiy; second row (standing): Vu Viet Dung, Mikhail Bankin, Tatiana E. Bilova, Elena R. Tarakhovskaya, Daria A. Romanyuk, Anastasia A. Kirpichnikova, Anton Shikov, Serafima Teplyakova, Vladislav V. Emelyanov; third row (standing): Anna Didio, Gregory A. Pozhvanov, Veronika Chantseva, Dmitry V. Suslov, Olga Shiroglazova, Galina N. Smolikova, Sergei S. Medvedev, Maria F. Shishova, Andrei A. Lipchinsky, Alexander Ilyin, Elena I. Sharova. Photo by Dr. Dmitry V. Grigoriev.

action. It was Prof. Polevoy and Dr. Tatiana S. Salamatova who demonstrated that the action of the $\mathrm{H}^{+}$-pump underlies numerous processes in plant physiology.

Professor Sergei S.Medvedev has been the head of the department since 1999, and his research is connected with plant cell and tissue polarity mechanisms; specifically, he is interested in gravitational biology and the plant calcium signalling system.

Currently, the department (https://bio.spbu.ru/faculty/departments/fbr/) employs four doctors of sciences and seven PhDs: D. Sci., Prof. Sergei S. Medvedev; D. Sci., Prof. Tamara V. Chirkova; D. Sci., Prof. Maria F. Shishova; D. Sci., Prof. Tatiana A. Gavrilenko; Dr., Associate Professor Natalia G. Osmolovskaya; Dr., Associate Professor Galina N.Smolikova; Dr., Associate Professor Elena I. Sharova; Dr., Associate Professor Vladislav V.Emelyanov; Dr., Associate Professor Elena R. Tarakhovskaya; Dr., Assistant Professor Tatiana E. Bilova; Dr., Assistant Professor Gregory A.Pozhvanov; Dr., Senior Research Fellow Dmitry V.Suslov; Research Fellow Roman K. Puzansky; Junior Research Fellow Ludmila N. Kuchaeva; Junior Re- search Fellow Anastasia A. Kirpichnikova; Research Engineer Andrei A. Lipchinsky; Engineer Yuri I.Shevtsov; Engineer Ludmila S. Sobol (Fig. 2).

The department's bachelor's and master's degree graduates are trained in modern physical chemistry, molecular biology, biochemical and physiological methods for research in the field of higher plant biology as well as lichen and algae biology.

The department's master's programs offer fundamental and applied science profiles. The Plant Physiology and Biochemistry profile (master's program) includes in-depth study of the fundamental basics of plant and algae functions through all of their organisational hierarchy levels - molecular, membrane, cellular and organism levels. The knowledge and skills gained in the master's programs empower graduates to be employed in modern plant biology science research centres in Russia and abroad.

The department team also actively participated in the development of the brand new master's profile, Molecular Biology and Agrobiotechnology of Plants. This 
program was launched just recently and includes the education of specialists for modern agricultural scientific research centres as well as for practical agriculture. Graduates are well trained in molecular biology, plant physiology and biochemistry, omics technologies and bioinformatics; they also gain practical skills for application in modern agriculture and phytotechnologies.

The department's research facilities include a gas chromatography-mass-spectrometry analytical complex, HPLC, various computer-coupled spectrophotometers and spectrofluorimeters, an atomic absorption spectrometer, a PAM fluorimeter, ionometers, etc. Plant membrane isolation and identification methods; vesicle membrane ion flux measurements using potentiometry and fluorescent probes; and light and fluorescence microscopy methods are well established in the department. Department faculty are experienced in omics technologies - transcriptomics, proteomics and metabolomics, as well as bioinformatics. During their studies in the department, students are provided with the most recent molecular, biotechnology and microscopy methods using the Research Resource Centres network of St. Petersburg State University (http://researchpark.spbu.ru/).

Department faculty not only teach bachelor's, master's and PhD students, but also actively encourage students to be involved in scientific research. Research in the department is led by the following groups:

1. Plant developmental biology. Gravitational biology of plants. Group leader - D. Sci., Prof. Sergei S. Medvedev.

2. Perception and transduction of phytohormonal and metabolite signals. Group leader - D. Sci., Prof. Maria F. Shishova.
3. Plant ecological physiology. Group leaders D. Sci., Prof. Tamara V. Chirkova; Dr., Associate Professor Vladislav V. Emelyanov.

4. Ion homeostasis and mechanisms of plant tolerance to heavy metals. Group leader - Dr., Associate Professor Natalia G. Osmolovskaya.

5. Physiology and biochemistry of plant cell wall extension growth. Group leader - Dr., Associate Professor Elena I. Sharova.

6. Biomechanics and metabolomics of cell wall extension growth. Group leader - Dr., Senior Research Fellow Dmitry V.Suslov.

7. Physiology of seeds. Group leader - Dr., Associate Professor Galina N. Smolikova.

8. Algae and lichens ecophysiology. Group leader Dr., Associate Professor Elena R. Tarakhovskaya.

9. Interdisciplinary research group "Plant glycated proteome". Group leaders - Dr., Associate Professor Andrej A. Frolov (Dept. of Biochemistry); Dr., Assistant Professor Tatiana E. Bilova (Dept. of Plant Physiology and Biochemistry).

In the past five years, department faculty have won one Russian Scientific Foundation grant, 13 grants from Russian Foundation for Basic Research and 14 grants from St. Petersburg State University, and have published 48 articles in journals indexed in Web of Science Core Collection and Scopus. The wide spectrum of research allows the department to keep its leading role as a research and education centre for graduating specialists that have developed skills in plant physical chemistry, molecular biology, and biochemistry and physiology research in higher plant and algae biology. 